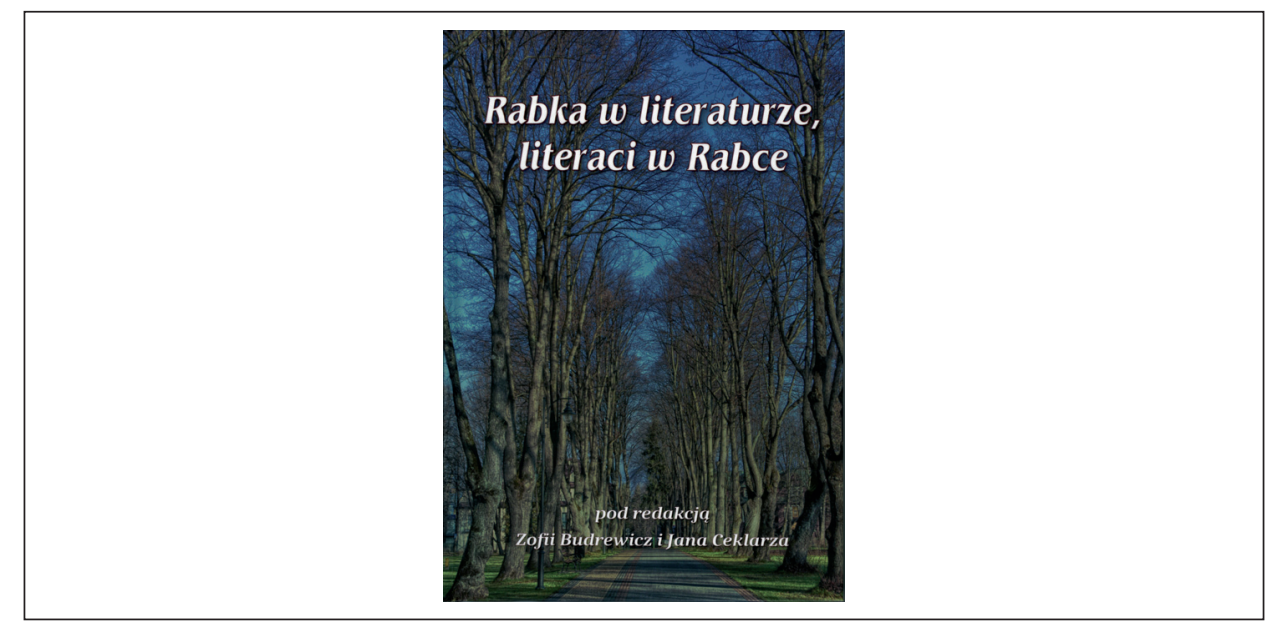

\title{
Rabczańskie opowieści nieznane
}

DOl: 10.19195/2084-4107.12.27

[rec.:] Rabka w literaturze, literaci w Rabce, red. Zofia Budrewicz, Jan Ceklarz, Stowarzyszenie Kulturowy Gościniec, Rabka-Zdrój 2018, ss. 276.

The unknown tales of Rabka-Zdrój

Słowa-klucze: Rabka-Zdrój, literatura, kultura, region

Keywords: Rabka, literature, culture, region

Rabka-Zdrój jest miejscowością mijaną w drodze do Zakopanego (dosłownie, jako że przechodzi przez nią słynna Zakopianka); leży u podnóży Gorców — gór schowanych $\mathrm{w}$ cieniu popularnych Tatr. I choć w latach międzywojnia wiązano z nią wielkie nadzieje, zapowiadając, że może ona powtórzyć letniskowy sukces Zakopanego („Od paru lat można tu zaobserwować interesujący proces przetwarzania się wsi w miasto, jaki Zakopane przeżywało temu 40 lat" $)$, obecnie wartościowana względem walorów krajobrazowo-klimatycznych miejscowości Skalnego Podhala wypada nie najlepiej. Jej pozycja wynika z marnej infrastruktury turystycznej (znów w porównaniu do tej zakopiańskiej), ta zaś powoduje, że przychodów z turystyki w regionie brakuje, co z kolei nie pozwala na inwestycje promocyjne.

Próbą przerwania tego zamkniętego koła jest publikacja tomu Rabka w literaturze, literaci $w$ Rabce pod redakcją Zofii Budrewicz i Jana Ceklarza. Założenia wstępne, przypisane zarówno tomowi, jak i całemu projektowi badawczemu, do-

\footnotetext{
1 J.K., Rabka, „Ziemia” 1931, nr 16, s. 195.
} 
tyczyły opisania i poddania badaniom literaturoznawczym mikrohistorii kultury Rabki-Zdroju ${ }^{2}$. Celem tych działań miało być nie tylko zaznaczenie Rabki na mapie badań naukowych, lecz także przybliżenie jej turystom. We wstępie do tomu czytamy: „monografia może przynieść [...] korzyści, ważne [...] dla rozwoju oferty kulturalnej uzdrowiska w aspekcie turystyki kulturowej"3. Promocyjny charakter publikacji potwierdza również fakt jej współfinansowania ze środków Europejskiego Funduszu Rolnego na rzecz Rozwoju Obszarów Wiejskich. Reklamowanie regionu poprzez prezentowanie jego kultury jest skutecznym narzędziem, a w wypadku podgorczańskiej Rabki zdaje się wyjątkowo potrzebne, między innymi aby odciążyć turystycznie przeładowane Tatry.

Idąc tropem tytułu, książkę można podzielić na dwie części: Rabka w literaturze - zawierającą analizy literackich obrazów Rabki, oraz Literaci w Rabce skupiającą się na akcentowaniu epizodów rabczańskich w biografiach twórców. $\mathrm{Na}$ tom składają się bowiem artykuły różnorodne pod względem podejmowanej tematyki i stopnia powiązania z Rabką. Spośród tych mniej rabczańsko zorientowanych można wymienić artykuły Krystyny Zabawy Rabczańskie dzieci w ,Wesotym przedszkolu" Marii Kownackiej i Anny Janickiej Uwagi o obrazie kobiety w „Pieśniach triesteńskich” Artura Ilgnera, w których relacja z Rabką objawia się jedynie przez biografię pisarza, natomiast analizowana twórczość, nawet jeśli inspirowana Rabką (przedszkolem rabczańskim u Kownackiej), jest uniwersalna. Pod względem literaturoznawczym przy toczone teksty stanowią ciekawe analizy poznawcze, zgrabnie badające mniej znane utwory.

W zbiorze znajdują się również artykuły opisujące historię miejscowości w nawiązaniu do biografii literatów. Podążając stopniowo po osi czasu od wieku XIX, odmalowują one dawny koloryt uzdrowiska, a także wskazują ważne dla jego funkcjonowania wydarzenia, instytucje i osobistości. Pierwszy tekst zbioru „Popierajmy polskie zdrojowiska i uzdrowiska” — pierwsze półwiecze rabczańskiego kurortu (1864-1918) autorstwa Małgorzaty Sadlik — zawiera fundamentalną wiedzę, która stanowi wprowadzenie do całego tomu. W większości analiz dla zarysowania kontekstu przedstawiono fragment dziejów Rabki. I tak czytając o Antonim Edwardzie Odyńcu, dowiadujemy się, jakimi zasadami rządziły się galicyjskie uzdrowiska drugiej połowy XIX wieku oraz jak wykształciła się „,moda na Rabkę". Natomiast podążając za studium powiastki Heleny Darowskiej, znajdujemy informację, że po kuracjuszy do Krakowa przyjeżdżali wozami wynajęci wcześniej górale. Status „miejsca lepszego” po 1918 roku nadaje Rabce Janina Barbara Górkiewiczowa, której trylogia Spłowiate lata według autorki poświęconego jej artykułu, Katarzyny Wądolny-Tatar, jest dowodem na wyjątkową popularność uzdrowiska wśród Polaków. Z kolei poznając twórczość Zdzisława Olszewskiego, dowiadujemy się wiele o szkolnictwie w uzdrowisku i strukturze społeczeństwa, w którym lokalni górale mieszali się z coraz większą liczbą przyjezdnej in-

2 Z. Budrewicz, J. Ceklarz, Wstęp, [w:] Rabka w literaturze, literaci w Rabce, red. Z. Budrewicz, J. Ceklarz, Rabka-Zdrój 2018, s. 5.

${ }^{3}$ Ibidem. 
teligencji. Szkic dotyczący Zofii Żurakowskiej i Haliny Poświatowskiej ujawnia natomiast zwyczaje i kulturę uzdrowiskową międzywojnia i lat pięćdziesiątych, a opowieść o ks. Mieczysławie Malińskim obrazuje specyficzne relacje z lokalnym duszpasterzem i przypomina, że w Rabce przebywał i nauczał ks. Karol Wojtyła. Analiza reportaży Ewy Owsiany przynosi między innymi informacje o egzekucjach dokonywanych na ludności żydowskiej przez SS, a portret Juliana Kawalca wskazuje na istotność jego postaci dla Rabki i Gorców. W szkicu o gorczańskiej twórczości Jana Fudali zarysowana jest tymczasem historia lokalnego ruchu regionalnego. Rabka w literaturze... jest więc pozycją nie tylko literaturoznawczą, lecz także — w dużej mierze — krajoznawczą.

Spośród różnorodnych szkiców zebranych w tomie należy wyróżnić te, które w dużym stopniu spełniają założenia tytułowe i wstępne, wynosząc Rabkę i okolice (szczególnie Gorce) na piedestał, wskazując na piękno krajobrazu i unikalność klimatu naturalnego oraz kulturalnego. Modelową analizę przestrzeni z wykorzystaniem nowoczesnych narzędzi geopoetyki przeprowadziła Maria Sienko w artykule Czuła pamięć ludzi i miejsca. Rabczańskie Gimnazjum dra Jana Wieczorkowskiego we wspomnieniach absolwenta - Zdzisław Olszewski ,Michat od Cyganów”. Ujęcie Rabki w perspektywie geografii emocji i wykorzystanie narzędzi geopoetyki Elżbiety Rybickiej, takich jak topografia emotywna, doprowadziły do stworzenia obrazu uzdrowiska inspirującego, kolorowego, wonnego i pociągającego. Autorka wspomnianego artykułu nie tylko zachęca do odwiedzenia Rabki, lecz także otwiera dyskusję nad twórczością Olszewskiego.

$\mathrm{Na}$ wyróżnienie zasługują również teksty Bolesława Farona Julian Kawalec i Rabka-Zdrój oraz Anny Mlekodaj Jan Fudala - poeta Gorców i Morza Czarnego. Oba te studia traktują o postaciach ważnych dla regionu, znanych (szczególnie w porównaniu z innymi opisywanymi w tomie twórcami), mieszkających w Rabce i zajmujacych się szerszą przestrzenią, bo Gorcami. Kawalec w przestrzeni gorczańskiej dostrzegał bowiem bodziec do egzystencjalnych przemyśleń senioralnych, natomiast Fudala, posługując się gwarą, traktował Gorce jako scenerię dla miłości i młodzieńczych uniesień. Ich twórczość jest różna, a jednak tak podobna, gdyż dająca konkretny materiał do analizy przestrzeni, który przez autorów artykułów został wykorzystany wzorcowo. Semantyczna ważność tych szkiców wskazuje na korzyści płynące ze spojrzenia na Rabkę i okoliczne góry jako całość i szukanie ich wspólnych literackich reprezentacji.

Artykuł Joanny Bercal Kropla światła. Rabka w reportażach Ewy Owsiany zdaje się nieświadomie nawiązywać do metodologii geopoetyki. Jednoznacznie bowiem określa Rabkę mianem „miejsca kształtującego reporterską osobowość Ewy Owsiany"4 i przedstawia wiele dowodów na poparcie tej tezy. Autorka wskazuje na funkcjonalność Rabki, wprost określa jej zalety, mówiąc między innymi, że Rabka pomaga „,kształcić się wielkim umysłom”.

4 J. Bercal, Kropla światła. Rabka w reportażach Ewy Owsiany, [w:] Rabka w literaturze..., s. 193.

5 Ibidem, s. 191. 
Kompleksowy charakter publikacji nadają prace poznawcze dotyczące mniej znanych dzieł i pisarzy, których można zaliczyć do istotnej grupy twórców regionu. Wskazują one na tendencję do utrwalania pewnych wyobrażeń o Rabce w ciągu dwóch ostatnich wieków. Są to między innymi artykuły Tadeusza Budrewicza i Krzysztofa Woźniakowskiego, w których pod lupę wzięto dzieła nieznane i zapomniane. Budrewicz nazywa napisane w Rabce przez Antoniego Edwarda Odyńca utwory „niewyszukanymi rymowankami”6, a Woźniakowski wielokrotnie podkreśla, że bohaterka jego analizy, Helena Darowska, to autorka „gruntownie dziś zapomniana"7. Należy też zwrócić uwagę na ślad, jaki tego typu twórczość zostawiła, i sposób, w jaki promowała uzdrowisko, docierając do całości społeczeństwa w formie rozrywkowych kolumn w gazetach codziennych i lekkiej literatury dziecięcej. Żeby zrozumieć wagę tego typu twórczości dla miejscowości i regionu, trzeba dostrzec, że to, co dziś zapomniane, kiedyś mogło oddziaływać na masy. Zestawienie omawianych artykułów z resztą tomu pozwala na szersze ujęcie obrazu Rabki w literaturze polskiej — nie tylko wysokiej, lecz także popularnej.

Artykuły zawarte w omawianej publikacji korespondują z sobą. Nawiązują do siebie, nie tylko snując wspólną opowieść o historii uzdrowiska, ale też z różnych perspektyw patrząc na tych samych twórców, a nawet na identyczne fragmenty ich utworów (przykładowo do jednego fragmentu z Michała od Cyganów Olszewskiego odwołują się Maria Sienko i Joanna $\mathrm{Bercal}^{8}$ ). Taka wielofunkcyjność cytatów daje wrażenie jedności i odrębności czegoś, co możemy nazwać literaturą rabczańską. Nasuwa się tu wspomnienie Władysława Orkana (którego twórczość była inspiracją niejednego z opisywanych $\mathrm{w}$ tomie artystów) - ojca literatury gorczańskiej, do której przynależą wszystkie utwory z Rabką w tle.

Tom Rabka w literaturze... niewątpliwie jest monografią potrzebną, ponieważ nie tylko promuje uzdrowisko, lecz także zwraca uwagę na kulturowe aspekty tej przestrzeni i jej literackie reprezentacje. Przypomina nazwiska zapomniane i zaznacza istotność tych osób, o których niewielu słyszało. Jest próbą skierowania zainteresowania badaczy na literaturę rabczańską, a więc i gorczańską, która schowana jest w cieniu wielkiej twórczości tatrzańskiej. Autorzy artykułów wykorzystują literaturę jako narzędzie promocyjne. Opisy pobytów w Rabce znakomitych pisarzy, takich jak Poświatowska, Iwaszkiewicz czy Odyniec, stają się swoistym poleceniem - warto przyjechać do miejsca, w którym znani i lubiani bawili się, leczyli się, płakali i wędrowali. Przywołanie obrazów Rabki w literaturze jest natomiast zachętą do odbycia podróży lekturowej, na przykład Gorce śladami Ka-

6 T. Budrewicz, Poeta i panny. Antoni Edward Odyniec w Rabce, [w:] Rabka w literaturze..., s. 42 .

${ }^{7}$ K. Woźniakowski, ,Wakacje Henrysia” - rabczańska powiastka Heleny Darowskiej z 1877 r., [w:] Rabka w literaturze..., s. 51.

8 J. Brecal, op. cit., s. 189; M. Sienko, Czuła pamięć ludzi i miejsca. Rabczańskie Gimnazjum dra Jana Wieczorkowskiego we wspomnieniach absolwenta - Zdzisław Olszewski „Michat od Cyganów”, [w:] Rabka w literaturze..., s. 119. 
walca, rabczańskie trasy Poświatowskiej czy szlak Michała od Cyganów. Jest to więc bodziec dla rozwoju turystyki w regionie.

Do tej pory to najsłynniejszy pisarz z tej okolicy, Władysław Orkan, zachęcał do odwiedzenia Gorców. Jego dom zamieniono w muzeum, a szlaki piesze prowadzące trasą jego literackich bohaterów, pomniki i miejsca przez niego rozsławione przyciągają turystów będących jednocześnie amatorami jego twórczości. Biorąc przykład z infrastruktury „orkanowskiej”, władze Rabki powinny zadbać o tego typu punkty turystyczne będące dowodami obecności w uzdrowisku innych pisarzy, o których traktuje tom. Myślę, że właśnie o takim rozwoju oferty kulturalnej redaktorzy książki pisali we wstępie. Patrząc na publikację jako element większej całości, trybik w machinie rozwoju regionu, można powiedzieć, że spełnia ona swoją funkcję. Warto dodać, że jej działanie jest dwupłaszczyznowe - z jednej strony oddziałuje na scenę polskiego literaturoznawstwa górskiego i uzdrowiskowego, z drugiej zaś przybliża Rabkę i Gorce amatorom literackim i turystom. Potwierdzeniem tego mariażu sfery naukowej i popularnej jest forma promocji książki, w ramach której odbył się wykład Elżbiety Rybickiej — mistrzyni geopoetyki polskiej. Ten eklektyczny charakter odpowiada założeniom statutowym Stowarzyszenia Kulturowy Gościniec - inicjatora i twórcy projektu badawczego, który zaowocował tomem Rabka w literaturze...

Maria Kościelniak

ORCID: 0000-0003-4438-2533 